\title{
Are Trichoderma atroviride and Trichoderma harzianum Effective to Control Fusarium Associated with Tomato Wilt?
}

\author{
WILFRIDUS ADYATMA PUTRANTO ${ }^{1}$, RULLY ADI NUGROHO ${ }^{1 *}$, PETRUS SUNU $^{*}$ \\ HARDIYANTA $^{2}$, AND DESTI CHRISTIAN CAHYANINGRUM ${ }^{1}$
}

\author{
${ }^{1}$ Faculty of Biology, Satya Wacana Christian University, Jalan Diponegoro 52-60 Salatiga 50711 Indonesia; \\ ${ }^{2}$ Faculty of Pharmacy, Sanata Dharma University, Jalan Affandi, Mrican Yogyakarta 55281 Indonesia.
}

\begin{abstract}
The pathogenic fungi, such as Fusarium in the rhizosphere of tomato (Solanum lycopersicum) negatively affects the yield and quality of the plant. A number of biological control agents have been used for protecting tomato plants against wilt diseases including various fungal species. The objective of this study was to evaluate the antagonism effects of Trichoderma atroviride and T. harzianum against the pathogen Fusarium sp. associated with tomato wilt. In this study, the antagonism of these Trichoderma spp. against the Fusarium sp. was tested in vitro by the dual culture technique, and the percentage inhibition of radial growth (PIRG) and the antagonism reaction (scale 1-5) were evaluated. The results showed that T. atroviride and T. harzianum led to $70.8 \%$ PIRG and scale 1 antagonism reaction, and 40.6\% PIRG and scale 3 antagonism reaction against Fusarium sp. associated with tomato wilt after 7 days of incubation, respectively. These results indicate that application of T. atroviride and T. harzianum may be promising approach for biological control of Fusarium wilt of tomato and may play an important role in sustainable agriculture.
\end{abstract}

Key words: antimicrobial activity, biological control, Fusarium wilt, tomato, Trichoderma spp.

Jamur patogen, seperti Fusarium di rizosfer tomat (Solanum lycopersicum) berdampak negatif terhadap hasil dan kualitas tanaman. Sejumlah agen pengendali hayati, termasuk berbagai jenis jamur telah digunakan untuk melindungi tanaman tomat dari penyakit layu. Penelitian ini bertujuan untuk mengevaluasi dampak antagonisme Trichoderma atroviride and T. harzianum terhadap patogen Fusarium sp. penyebab layu pada tomat. Dalam penelitian ini antagonisme Trichoderma spp. terhadap Fusarium sp. diuji secara in vitro dengan teknik kultur ganda, dan persentase penghambatan pertumbuhan radial (PPPR) dan reaksi antagonisme (skala 1-5) dievaluasi. Hasil penelitian menunjukkan bahwa T. atroviride dan T. harzianum masing-masing menyebabkan 70,8\% PPPR dan reaksi antagonisme skala 1, dan 40,6\% PPPR dan reaksi antagonisme skala 3 terhadap Fusarium sp. penyebab layu pada tomat setelah 7 hari inkubasi. Hasil ini mengindikasikan bahwa aplikasi T. atroviride dan T. harzianum dapat menjadi pendekatan yang menjanjikan untuk pengendalian hayati layu Fusarium tomat dan dapat memainkan peran penting dalam pertanian berkelanjutan.

Kata kunci: aktivitas antimikroba, pengendalian biologi, layu Fusarium, tomat, Trichoderma spp.

Fusarium is one of the most economically important genera of fungal plant pathogens, causing significant crop losses and contamination of grain by mycotoxins on a global basis (Burgess and Bryden 2012). The species most commonly involved include $F$. graminearum and F. oxysporum (Dean et al. 2012). Fusarium colonizes the xylem vessels producing mycelium and conidia. The characteristic wilt symptoms appear as a result of water stress, mainly due to vessel clogging (Beckman 1987).

Fusarium wilt of tomato is commonly caused by the fungal pathogens, $F$. oxysporum, $F$. solani or $F$. equiseti (Isaac et al. 2018; Ayele et al. 2021). The most familiar formae species to tomato is Fusarium oxysporum f.sp. lycopersici (Isaac et al. 2018; Srinivas et al. 2019).

*Corresponding author: Phone: +62-298-321212 ; Fax: +62298-321433; E-mail: rully.nugroho@uksw.edu
Fusarium become harmful organisms for tomato plants (Solanum lycopersicum) because it will cause tomato plants to be damaged and harvest failure. Tomato plants that are attacked by $F$. oxysporum will turn yellow on the leaves, the plants will wither, growth will be stunted, the fruit will rot, then the plant will die and necrosis on one side of the stem. Symptoms of necrosis begin with a change in color, then gradually dry up (Wiam et al. 2019). Seedlings exposed to $F$. oxysporum f. sp. lycopersici experience slow growth, while plants infected with Fusarium cause root rot partially or completely, leaves turn yellow and then curl, plants are stunted, wilted, and may die completely (Blancard 2012; Hermann and Lecomte 2019). Fusarium can produce mycotoxins tricotisin, fumonisin, intentin, zearalenone, beauverisin, moniliformin, fusarin, fusaric acid, and fusaproliferin which can affect human and animal health when ingested (Wang et al. 2011). 
Farmers use chemical fungicides such as benomyl, mancozeb, dithiocarbamate, and phenylamide to treat problems caused by pathogenic fungi (Apriani et al. 2014; Sumardiyono et al. 1995; Worku and Sahela 2018). However, long-term use of fungicides can affect non-target organisms such as earthworms, microbes and humans (Patel et al. 2014). Biological control technology plays an important role in overcoming diseases in plants that are promising and safe for humans and do not pollute the environment (Kang 2019).

Currently, there are more than $60 \%$ of biological control that use Trichoderma species (Abbey et al. 2019). Trichoderma species can be found at temperatures of $25-35^{\circ} \mathrm{C}$ (Hajieghrari et al. 2008) in tropical soils, and can also be found on soils in forest, agricultural, and grassland areas (Kubicek et al. 2003). As many as 35 of the 260 Trichoderma species that live in roots (Digamber 2017) have good economic importance because of their ability to produce enzymes, antibiotics, and secondary metabolites so that they can be used as effective biological control agents (Blaszczyk et al. 2014). Trichoderma is known as a biological control agent because it can survive in all kinds of conditions, has a high reproductive rate, is efficient in the absorption of nutrients from its surroundings, and shows aggressive resistance to a fungal pathogen (Misra and Prasad 2003; Pandya et al. 2011).

Zhang et al. (2017) stated that Trichoderma showed antagonistic behaviour against several phytopathogenic organisms, including bacteria, nematodes and fungi by inhibiting their growth. Trichoderma asperellum (Jiang et al. 2016), T. harzianum (Ezziyyani et al. 2007), T. koningiopsis (Delgado et al. 2018), and T. virens (Tomah et al. 2020) have been shown to be highly effective in the management of Phytophthora capsici. According to Jiang et al. (2016) hyphae from isolates of T. asperellum can penetrate hyphae and spores of $P$. capsici in the form of mycoparasitism which causes hyphal cells to degrade. Mycoparasitism involves cell wall-degrading enzymes that allow mycoparasitic fungi to drill holes into other fungi and extract nutrients for their own growth (Cao et al. 2009). Trichoderma strains produce antibiotics or low molecular weight compounds that are useful for inhibiting the growth of plant pathogens such as 6-pentyl-pyrone (Jelen et al. 2014), viridiofungin (El-Hasan et al. 2009), and gliotoxin (Roberts and Lumsden 1990).

Trichoderma as an interesting model for being studied about interactions between plant hosts and its symbionts should be considered as a biological control alternative in the green economy era which aims to maintain human health, protect the environment, and as a promotional agent sustainable agriculture (LopezBucio et al. 2015; Guzmán-Gusmán et al. 2017; Sood et al. 2020). Therefore, this study was conducted to test whether T. atroviride or T. harzianum can overcome the pathogen Fusarium associated with tomato wilt so that these two Trichoderma species can be used as biocontrol agents.

\section{MATERIALS AND METHODS}

Isolation of Fungal Strains. The Trichoderma atroviride and T. harzianum isolates were obtained from KPTT Agricultural Training Center, Salatiga, Indonesia and recultured in Potato Dextrose Agar (PDA, Merck). Trichoderma spp. isolates were incubated at $25^{\circ} \mathrm{C}$ for 7 days (Ramteke 2019). The patogen, Fusarium sp. was isolated according to a procedure developed by Leslie and Summerell (2006) from the wilt infected roots of tomato plants which were collected from KPTT Agricultural Training Center, Salatiga, Indonesia. The isolates were grown on Komada's selective medium and incubated at $30^{\circ} \mathrm{C}$ for 7 days, then subcultured on PDA (Merck) and incubated at $25^{\circ} \mathrm{C}$ for 5 days (Leslie and Summerell 2006). Fusarium sp. isolate was identified on the basis of cultural and morphological characteristics which included colony color, pigmentation, surface texture, colony edge, conidiophores, septate or anseptate hyphae, presence or absence of phialid, conidia color, conidia shape, macrocoonidia or microconidia shape, presence or absence of chlamydospores (Mwaniki et al. 2011; Sharma and Singh 2014; Rai et al. 2016; Redda et al. 2018).

In vitro Experiment. The effects of Trichoderma spp. on Fusarium were tested by the dual culture technique as described by Redda et al. (2018). The Trichoderma spp. isolates and Fusarium sp. to be tested were cultured separately on PDA for 7 days. After 7 days, $5 \mathrm{~mm}$ mycelial plugs (taken from the edge of fungal colonies) of each species to be tested were transferred to PDA plates using cork borer. The mycelial plug of Trichoderma species and Fusarium sp. was placed opposite side to each other on a PDA surface. PDA plates inoculated with Fusarium sp. was included as negative control. All plates were incubated at $25 \pm 2{ }^{\circ} \mathrm{C}$ and observations were made after 7 days of incubations. The percentage inhibition of radial growth (PIRG) was calculated by the following formula 
Table 1 The percentage inhibition of radial growth (PIRG) in dual culture assay. Results are expressed as mean \pm standard deviation of PIRG after 1- to 7-day incubation. ND $=$ Not Determined

\begin{tabular}{lrrrrrrr}
\hline Trichoderma & \multicolumn{6}{c}{ Percentage inhibition of radial growth (PIRG) (\%) } \\
\cline { 2 - 8 } strains & 1-day & 2-day & \multicolumn{1}{c}{ 3-day } & 4-day & 5-day & 6-day & 7-day \\
\hline T. atroviride & ND & $2.9 \pm 11.94$ & $36.5 \pm 6.50$ & $51.7 \pm 3.39$ & $60.5 \pm 2.44$ & $66.7 \pm 2.34$ & $70.8 \pm 2.03$ \\
T. harzianum & ND & ND & $5.0 \pm 8.69$ & $6.1 \pm 7.08$ & $21.3 \pm 5.67$ & $32.3 \pm 4.46$ & $40.6 \pm 3.76$ \\
\hline
\end{tabular}

(Sharfuddin and Mohanka 2012):

$P I R G=\left(R_{1}-R_{2}\right) / R_{l} \times 100$

where $R_{I}=$ radial growth of Fusarium sp. in control (cm), $R_{2}=$ radial growth of Fusarium $\mathrm{sp}$. in dual culture tests with Trichoderma spp. (cm). The antagonism reaction of Trichoderma isolates were score using a scale of 1 to 5 after 7 days of incubation, where $1=$ Trichoderma overgrew the entire growth of the Fusarium sp., 2 = Trichoderma overgrew at least twothird of the medium surface, 3 = Trichoderma and Fusarium sp. each colonized one half of the medium surface, $4=$ Fusarium $\mathrm{sp}$. colonized at least two-third of the medium surface, $5=$ Fusarium sp. overgrew Trichoderma (Bell et al. 1982).

Statistical Analysis. Data were analysed using SPSS 22 (SPSS Inc., Chicago, IL). All data were calculated and analysed statistically using $t$ test $(P \leq$ 0.05 ) to determine differences between treatments. The table was drawn using Microsoft Excel 2016.

\section{RESULT}

Isolation and Identification of Fusarium sp. Results showed that Fusarium sp. had well-defined macroscopic characteristics (Fig 1). Fusarium sp. has pink mycelia in the center and white at the edges. Fusarium sp. underwent pigmentation changes where the mycelia of Fusarium sp. on the first and second day it is white and on the fifth day it changes color to a slightly brownish beige. In addition, the surface texture of Fusarium sp. has a cotton-like texture and has a filamentous shape and colony edge. Conidiophores Fusarium sp. are dendritic conidiophores, possessing pseudohyphae, but no phialids. Color of conidia Fusarium sp. is a fusoidal green with thickened walls at the ends. Fusarium has chlamydiophores that are shaped like lumps on hyphae.

The Effects of Trichoderma spp. on Fusarium sp. using In Vitro Assays. Table 1 showed the PIRG observed on the first until the seventh day of the test. The inhibitions of T. atroviride and T. harzianum are observed from the second and the third day of incubation, respectively. Both isolates were shown to have inhibitory activity on Fusarium pathogen in vitro (Table 1). Trichoderma atroviride was significantly $(P$ $<0.05$ ) more effective as it was able to inhibit at $70.8 \%$ of Fusarium sp. after 7 days of incubation, while $T$. harzianum demonstrated lower PIRG (40.6\%) after 7 days of incubation. In Fig 2, a 7 day test of Fusarium sp. grown with $T$. atroviride and $T$. harzianum clearly demonstrated that the mean scale for antagonism of $T$. atroviride was also significantly higher than $T$. harzianum, i.e. scale of 1 and 3 , respectively.

\section{DISCUSSION}

The isolate obtained from tomato rhizosphere soil was confirmed as Fusarium sp. The morphological characteristics are the same as mentioned by Gordon (2017) and Srinivas et al. (2019). The result of this study supports findings in other studies that characterized Fusarium as most important fungal in tomato plantation areas in defferent countries of the world (Grattidge and O'Brien 1982; Jones et al. 1991; Steinkellner et al. 2005; Rozlianah and Sariah 2006; Amini 2009; Chehri 2016).

Trichoderma species are fungi that have the potential to control pathogenic fungi, has a low impact on soil balance, and has minimal impact on damage to non-target organisms (Sood et al. 2020). Consistent with previous findings, this study confirms the antagonism effect of $T$. atroviride and T. harzianum against the pathogen Fusarium sp. associated with tomato wilt. The antagonism effects of both Trichoderma spp. against Fusarium sp. showed that both Trichoderma spp. affecting the development pattern of Fusarium sp. colonies. Trichoderma colonies presented a faster growth in the plates of dual cultures, being capable of growing on the Fusarium sp., preventing their mycelial development by nutrient and space competition as found by Filizola et al. (2019).

Moreover, based on the antagonistic activity (Soytong 1988), this study indicated that $T$. atroviride exhibited a very high antagonistic activity against Fusarium sp. ( $>75 \%$ PIRG), while T. harzianum 


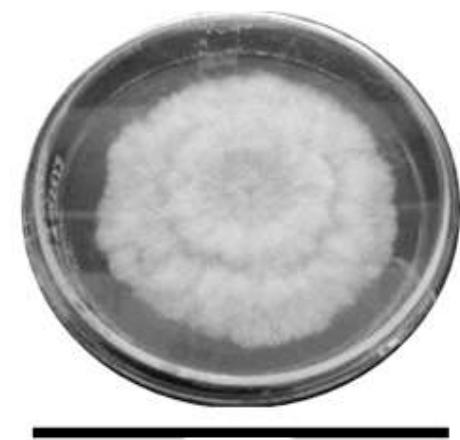

(a)

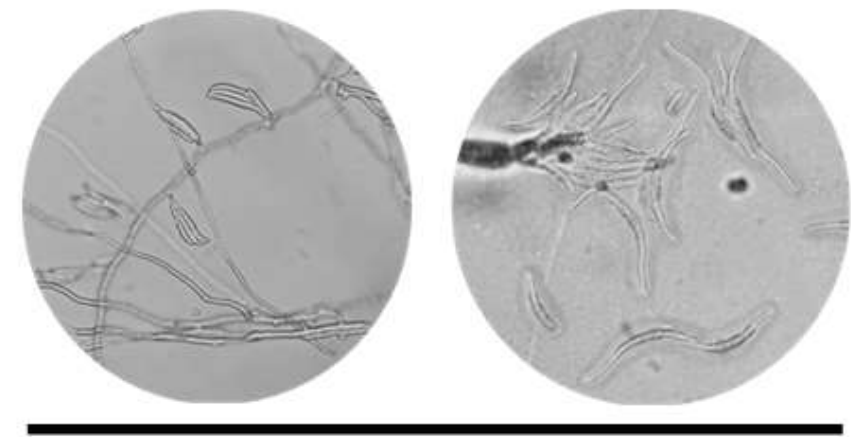

(b)

Fig 1 Characterization of Fusarium sp. by macroscopic morphology in PDA medium after 7 days. a. Colony morphology; b. Conidiosphores and conidia. Magnification $\times 400$.

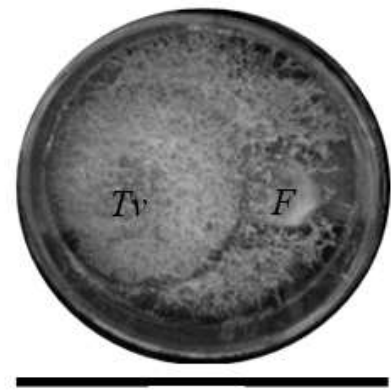

(a)

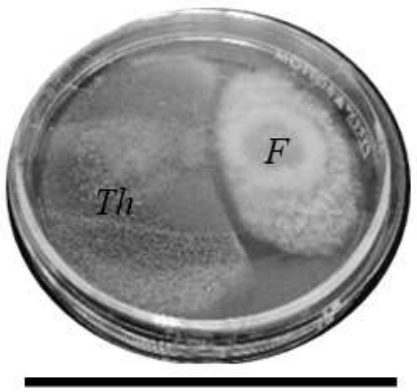

(b)

Fig 2 Dual culture assay after 7 days of incubation. a. Trichoderma atroviride/Fusarium sp.; b. Trichoderma harzianum/Fusarium sp.; Tv: Trichoderma atroviride; Th: Trichoderma harzianum; F: Fusarium sp.

showed low antagonistic activity against Fusarium sp. ( $<50 \%$ PIRG). This study shows that $T$. atroviride demonstrated more antagonistic activity than observed by Stracquadanio et al. (2020). Stracquadanio et al. (2020) found that $T$. harzianum did not reduce the growth of Fusarium moniliforme. This shows that not all Trichoderma strains are able to inhibit the in vitro growth of Fusarium.

Previous studies have shown that Trichoderma has several modes of action, including production of antibiotics and cell wall degrading enzymes, competition for key nutrients, parasitism, stimulation of plant defense mechanisms and combination of these possibilities (Fravel 1988; Larkin and Fravel 1988; Roberts and Lumsden 1990; El-Hasan et al. 2009; John et al. 2010; Jelen et al. 2014; Jiang et al. 2016; Taghdi et al. 2015). According to Howel (2006) and Zhang et al. (2017), Trichoderma exhibit antagonistic behavior against several phytopathological organisms, especially fungi by inhibiting their growth either by direct interactions (e.g. hyperparasitism, competition for nutrient and space, and antibiosis). Kubicek et al. (2011) detected a number of genes for the synthesis of popyketide synthases (PKSs) and non-ribosomal peptide synthetases (NRPSs) as the most outstanding properties of $T$. atroviride. By contrast, other studies have reported repression of this gene category in $T$. harzianum (Viera et al. 2013; Steindorff et al. 2014). However, all of these suggestions need to be further clarified. Thus, it can be concluded that this study indicates that application of $T$. atroviride and $T$. harzianum may be promising approach for biological control of Fusarium wilt of tomato and may play an important role in sustainable agriculture.

\section{REFERENCES}

Abbey JA, Percival D, Abbey L, Asiedu SK, Prithiviraj B, Schilder A. 2019. Biofungicides as alternative to synthetic fungicide control of grey mould (Botrytis cinerea) - Prospects and challenges. Biocontrol Sci Technol. 29(3):207-228. doi: 10.1080/09583157.2 018.1548574 .

Amini J. 2009. Physiological race of Fusarium oxysporum $\mathrm{f}$. sp. lycopersici in Kurdistan Province of Iran and reaction of some tomato cultivars to race 1 of pathogen. Plant Pathol J. 8(2):68-73. doi : 10.3923/ppj.2009.68.73.

Apriani L, Suprapta DN, Temaja IGRM. 2014. Uji efektivitas fungisida alami dan sintetis dalam 
mengendalikan penyakit layu Fusarium pada tanaman tomat yang disebabkan oleh Fusarium oxysporum f.sp. lycopersici. E-J Agroekoteknol Trop. 3(3): 137-147.

Ayele TM, Gebremariam GD, Patharajan S. 2021. Isolation, identification and in vitro test for the biocontrol potential of Trichoderma viride on Fusarium oxysporum f. sp. lycopersici. The Open Agric J. 15:1020. doi: 10.2174/1874331502115010010.

Beckman CH. 1987. The nature of wilt diseases of plants. Minnesota: American Phytopathological Society.

Bell DK, Wells HD, Markham CR. 1982. In vitro antagonism of Trichoderma species against six fungal plant pathogens. Phytopathol 72(4):379-382. doi: 10.1094/Phyto-72-379.

Blancard D. 2012. Tomato diseases: Identification, biology, and control: A colour handbook. London: CRC Press.

Blaszczyk L, Siwulski M, Sobieralski K, Lisiecka J, Jędryczka M. 2014. Trichoderma spp. -Application and prospects for use in organic farming and industry. $\mathrm{J}$ Plant Prot Res. 54(4):309-317. doi: 10.2478/jppr-20140047.

Burges LW, Bryden WL. 2012. Fusarium: A ubiquitous fungus of global significance. Microbiol Aust. 33(1):22-25. doi: 10.1071/MA12022.

Cao R, Liu X, Gao K, Mendgen K, Kang Z, Gao J, Dai Y, Wang X. 2009. Mycoparasitism of endophytic fungi isolated from reed on soilborne phytopathogenic fungi and production of cell wall-degrading enzymes in vitro. Curr Microbiol. 59(6):584-592. doi: 10.1007/s00284009-9477-9.

Chehri K. 2016. Molecular identification of pathogenic Fusarium species, the causal agents of tomato wilt in western Iran. J Plant Prot Res. 56(2):143-148. doi: 10.1515/jppr-2016-0024.

Dean R, van Kan JAL, Pretorius ZA, Hammond-Kosack KE, Di Pietro A, Spanu PD, Rudd JJ, Dickman M, Kahmann R, Ellis J, Foster GD. 2012. The top 10 fungal pathogens in molecular plant pathology. Molec Plant Pathol. 13(4):414-430. doi: 10.1111/j.13643703.2011.00783.x.

Delgado R-E, Ruíz L-JDJ, Rico M-O, Velasquez Q-J, Mendoza H-JL. 2018. Effect of Trichoderma on growth and sporangia production of Phytophthora capsici. J Agric Sci. 10(6):8-15. doi: 10.5539/jas.v10n6p8.

Digamber PS. 2017. Geographical diversity analysis of Trichoderma spp. isolates based on sequence related amplified polymorphism (SRAP) marker. Latur: College of Agricultural Biotechnology.

El-Hasan A, Walker F, Schone J, Buchenauer H. 2009. Detection of viridiofungin $\mathrm{A}$ and other antifungal metabolites excreted by Trichoderma harzianum active against different plant pathogens. Eur J Plant Pathol. 124:457-470. doi: http://dx.doi.org/10.1007/s10658-
009-9433-3.

Ezziyyani M, Requena ME, Egea-Gilabert C, Candela ME. 2007. Biological control of Phytophthora root rot of pepper using Trichoderma harzianum and Streptomyces rochei in combination. J Phytopathol. $155(6): 342-349$. doi: $10.1111 / \mathrm{j} .1439$ 0434.2007.01237.x.

Filizola PRB, Luna MAC, de Souza AF, Coelho IL, Laranjeira D, Campos-Takaki GM. 2019. Biodiversity and phylogeny of novel Trichoderma isolates from mangrove sediments and potential of biocontrol against Fusarium strains. Microb Cell Fact. 18(1):89. doi: 10.1186/s12934-019-1108-y.

Fravel DR. 1988. Role of antibiosis in the biocontrol of plant diseases. Annu Rev Phytopathol. 26(1):75-91. doi: 10.1146/annurev.py.26.090188.000451.

Gordon TR. 2017. Fusarium oxysporum and the fusarium wilt syndrome. Annu Rev Phytophatol. 55(1):23-39. doi: 10.1146/annurev-phyto-080615-095919.

Grattidge R, O'Brien RG. 1982. Occurence of third race of Fusarium wilt of tomatoes in Queensland. Plant Dis. 66(2):165-166. doi: 10.1094/PD-66-165.

Guzmán-Guzmán P, Alemán-Duarte MI, Delaye L, HerreraEstrella A, Olmedo-Monfil V. 2017. Identification of effector-like proteins in Trichoderma spp. and role of a hydrophobin in the plant-fungus interaction and mycoparasitism. BMC Gen. 18(1):16. doi: 10.1186/s12863-017-0481-y.

Hajieghrari B, Giglou T-M, Mohammadi MR, Davari M. 2008. Biological potential of some Iranian Trichoderma isolates in the control of soil borne plant pathogenic fungi. Afr J Biotechnol. 7(8):967-972. doi: 10.4314/AJB.V7I8.58586.

Hermann E-V, Lecomte C. 2019. Current status of Fusarium oxysporum formae speciales and races. Phytopathol. 109(4):512-530. doi: 10.1094/PHYTO-08-18-0320RVW.

Howell CR. 2006. Understanding the mechanisms employed by Trichoderma virens to effect biological control of cotton diseases. Phytopathol. 96(2):178-180. doi: 10.1094/PHYTO-96-0178.

Isaac MR, Leyva-Mir SG, Sahagún-Castellanos J, CámaraCorreia K, Tovar-Pedraza JM, Rodríguez-Pérez JE. 2018. Occurence, identification, and pathogenicity of Fusarium spp. associated with tomato wilt in Mexico. Not Bot Horti Agrob. 46(2):484-493. doi: $10.15835 /$ nbha46211095.

Jelen H, Błaszczyk L, Chelkowski J, Rogowicz K, Strakowska J. 2014. Formation of 6-N-pentyl-2Hpyran-2-one (6-PAP) and other volatiles by different Trichoderma species. Mycological Progress. 13(3):589-600. doi: 10.1007/s11557-013-0942-2.

Jiang H, Zhang L, Zhang J-Z, Ojaghian MR, Hyde KD. 
2016. Antagonistic interaction between Trichoderma asperellum and Phytophthora capsici in vitro. J Zhejiang Univ-Sci B (Biomed \& Biotechnol). 17(4):271-281. doi: 10.1631/jzus.B1500243.

John RP, Tyagi RD, Prevost D, Brar SK, Pouleur S, Surampalli RY. 2010. Mycoparasitic Trichoderma viride as a biocontrol agent against Fusarium oxysporum f. sp. adzuki and Pythium arrenomanes and as a growth promoter of soybean. Crop Prot. 29(12):1452-1459. doi: 10.1016/J.CROPRO.2010.08.004.

Jones JB, Stal JP, Zitter TA. 1991. Compendium of tomato disease. Minnesota: The American Pathological Society Press. 73 pp.

Kang L. 2019. Overview: Biotic signalling for smart pest management. Philos Trans R Soc Lond B Bio Sci. 374(1767):20180306. doi: 10.1098/rstb.2018.0306.

Kubicek CP, Bissett J, Druzhinina I, Kullnig-Gradinger C, Szakacs G. 2003. Genetic and metabolic diversity of Trichoderma: A case study on South-East Asian isolates. Fungal Genet Biol. 38(3):310-319. doi: 10.1016/S1087-1845(02)00583-2.

Kubicek, CP, Herrera-Estrella A, Seidl-Seiboth V, Martinez DA, Druzhinina IS, Thon M, et al. 2011. Comparative genome sequence analysis underscores mycoparasitism as the ancestral life style of Trichoderma. Genome Biol. 12:R40. doi: 10.1186/gb2011-12-4-r40.

Larkin RP, Fravel DR. 1988. Efficacy of various fungal and bacterial biocontrol organisms for control of Fusarium wilt of tomato. Plant Dis. 82(9):1022-1028. doi: 10.1094/PDIS.1998.82.9.1022.

Leslie JF, Summerell BA. 2006. The Fusarium laboratory manual. Iowa: Blackwell Publishing.

Lopez-Bucio J, Pelagio-Flores R, Herrera-Estrella A. 2015. Trichoderma as biostimulant: Exploiting the multilevel properties of a plant beneficial fungus. Sci Hortic. 196:109-123. doi: 10.1016/j.scienta.2015.08.043.

Misra AK, Prasad B. 2003. Trichoderma- A genus for biocontrol. In: Shrivastava RP. (ed) Biopesticide and bioagents in integrated pest management of agriculture crops. Lucknow: International Book Distribution Co.

Mwaniki PK, Abang MM, Wagara IN, Wolukau JN, Schroers H-J. 2011. Morphology, pathogenicity and molecular identification of Fusarium spp. from wilting eggplants in Tanzania. Afr Crop Sci Con Proc 10:217221.

Pandya JR, Sabalpara AN, Chawda SK. 2011. Trichoderma: A particular weapon for biological control of phytopathogens. Int J Agric Technol. 7(5):1187-1191.

Patel N, Desai P, Patel N, Jha A, Gautam HK. 2014. Agronanotechnology for plant fungal disease management: A review. Int J Curr Microbiol App Sci, 3(10):71-84.
Rai S, Kashyap PL, Kumar S, Srivastava AL, Ramteke PW. 2016. Identification, characterization and phylogenetic analysis of antifungal Trichoderma from tomato rhizosphere. Springer Plus. 5(1):1939. doi: 10.1186/s40064-016-3657-4.

Ramteke AS. 2019. Trichoderma species: Isolation, characterization, cultivation and their role as effective biopesticides. Int J Res Rev. 6(6):315-320.

Redda ET, Ma J, Mei J, Wu B, Jiang X. 2018. Antagonistic potential of different isolates of Trichoderma against Fusarium oxysporum, Rhizoctonia solani, and Botrytis cinereal. Eur J Exp Biol. 8(2):12. doi: 10.21767/22489215.100053.

Roberts DP, Lumsden RD. 1990. Effect of extracellular metabolites from Gliocladium virens on germination of sporangia and mycelial growth of Pythium ultimum. Phytopathol. 80(5):461-465. doi: 10.1094/PHYTO-80461.

Rozlianah FS, Sariah M. 2006. Characterization of Malaysisa isolation of Fusarium from tomato and pathogenicity testing. Res J Microbiol. 1(3):266-272. doi: 10.3923/jm.2006.266.272.

Sharfuddin C, Mohanka R. 2012. In vitro antagonism of indigenous Trichoderma isolates against phytopathogen causing wilt of lentil. Int J Life Sci Pharma Res. 2(3):195-202.

Sharma KK, Singh US. 2014. Cultural and morphological characterization of rhizospheric isolates of fungal antagonist Trichoderma. J App Nat Sci. 6(2):451-456. doi: 10.31018/jans.v6i2.481.

Sood M, Kapoor D, Kumar V, Sheteiwy MS, Ramakrishnan M, Landi M, Araniti F, Sharma A. 2020. Trichoderma: The "secrets" of a multitalented biocontrol agent. Plants. 9(6):762. doi: 10.3390/plants9060762.

Soytong K. 1988. Identification of species of Chaetomium in the Philippines and screening for their biocontrol properties against seedborne fungi on rice [Ph.D. Thesis]. Laguna (PH): University of the Philippines Los Baños.

Srinivas C, Devi DN, Murthy K, Mohan CD, Lakshmeesha TR, Singh BP, Kalagatur NK, Niranjana SR, Hashen A, Alqarawi AA, Tabassum B, Abd_Allah EF, Nayaka SC, Srivastava RK. 2019. Fusarium oxysporum f. sp. lycopersici causal agent of vascular wilt disease of Tomato: Biology to diversity- A review. Saudi J Biol Sci. 26(7):1315-1324. doi: 10.1016/j.sjbs.2019.06.002.

Steindorff AS, Ramada MHS, Coelho ASG, Miller RNG, Pappas GJJr, Uhloa CJ, Noronha EF. 2014. Identification of mycoparasitism-related genes against the phytopathogen Sclerotinia sclerotiorum through transcriptome and expression profile analysis in Trichoderma harzianum. BMC Genomics 15:204. doi: 10.1186/1471-2164-15-204. 
Steinkellner S, Mammerler R, Vierheilig H. 2005. Microconidia germination of the tomato pathogen Fusarium oxysporum in the presence of root exudates. $\mathrm{J}$ P lant Interac. 1 ( 1 ): 23 - 30 . d o i : 10.1080/17429140500134334.

Stracquadanio C, Quiles JM, Meca G, Cacciola SO. 2020. Antifungal activity of bioactive metabolites produced by Trichoderma asperellum and Trichoderma atroviride in liquid medium. J Fungi 6:263. doi: 10.3390/jof6040263.

Sumardiyono C, Pusposendjojo N, Trisnowati S. 1995. Ketahanan beberapa jamur patogen terhadap fungisida. J Perlindungan Tanaman Indones 1(1):51-55. doi: 10.22146/jpti.9350.

Taghdi Y, Hermosa R, Domínguez S, Rubio MB, Essalmani H, Nicolas C, Monte E. 2015. Effectiveness of composts and Trichoderma strains for control of Fusarium wilt of tomato. Phytopathol Mediterr. 54(2):232-240. doi: 10.14601/Phytopathol_Mediterr15226.

Tomah AA, Alamer ISA, Li B, Zhang J-Z. 2020. A new species of Trichoderma and gliotoxin role: A new observation in enhancing biocontrol potential of $T$. virens against Phytopthora capsica on pepper. Biol Control. 145:104261. doi: 10.1016/j.biocontrol.2020.104261.
Vieira PM, Coehlo AS, Steindorff AS, De Siqueira SJ, Silva Rdo N, Ulhoa CJ. 2013. Identification of differentially expressed genes from Trichoderma harzianum during growth on cell wall of Fusarium solani as a tool for biotechnological application. BMC Genomics 14:177. doi: 10.1186/1471-2164-14-177.

Wang H, Xiao M, Kong F, Chen S, Dou H, Sorrell T, Li R, Xu Y. 2011. Accurate and practical identification of 20 Fusarium species by seven-locus sequence analysis and reverse line blot hybridization, and an in vitro antifungal susceptibility study. J Clinical Microbiol. 49(5):1890-1898. doi: 10.1128/JCM.02415-10.

Wiam B, Wassima L, Abderrahmene D, Omar G. 2019. Experimental approach for easy identify Fusarium wilt of tomato. World J Environ Biosci, 8(2):44-48.

Worku M, Sahela S. 2018. Review on disease management practice of tomato wilt caused Fusarium oxysporum in case of Ethiopia. J Plant Pathol Microbiol. 9(11):1000460. doi: 10.4172/2157-7471.1000460.

Zhang J, Chen GY, Li XZ, Hu M, Wang BY, Ruan BH, Zhou H, Zhao LX, Zhou J, Ding ZT, Yang YB. 2017. Phytotoxic, antibacterial, and antioxidant activities of mycotoxins and other metabolites from Trichoderma sp. Nat Prod Res. 31(23):2745-2752. doi: 10.1080/14786419.2017.1295235. 